\title{
Why does surface ozone peak before a typhoon landing in southeast China?
}

\author{
Y. C. Jiang ${ }^{1}$, T. L. Zhao ${ }^{1}$, J. Liu ${ }^{2,3}$, X. D. Xu ${ }^{4}$, C. H. Tan ${ }^{1}$, X. H. Cheng ${ }^{5}$, X. Y. Bi ${ }^{6,7}$, J. B. Gan ${ }^{8}$, J. F. You ${ }^{9}$, and \\ S. Z. Zhao ${ }^{10}$ \\ ${ }^{1}$ Collaborative Innovation Center on Forecast and Evaluation of Meteorological Disasters, Key Laboratory for \\ Aerosol-Cloud-Precipitation of China Meteorological Administration, Nanjing University of Information \\ Science and Technology, Nanjing 210044, China \\ ${ }^{2}$ School of Atmospheric Sciences, Nanjing University, Nanjing 210023, China \\ ${ }^{3}$ Department of Geography and Planning, University of Toronto, Toronto, M5S 3G3, Canada \\ ${ }^{4}$ State Key Laboratory of Severe Weather, Chinese Academy of Meteorological Sciences, Beijing 100081, China \\ ${ }^{5}$ Institute of Atmospheric Composition, Key Laboratory of Atmospheric Chemistry of China Meteorological \\ Administration, Chinese Academy of Meteorological Sciences, Beijing 100081, China \\ ${ }^{6}$ State Key Laboratory of Atmospheric Boundary Layer Physics and Atmospheric Chemistry (LAPC), \\ Institute of Atmospheric Physics, Chinese Academy of Sciences, Beijing 100029, China \\ ${ }^{7}$ Institute of Tropical and Marine Meteorology/Guangdong Provincial Key Laboratory of Regional \\ Numerical Weather Prediction, China Meteorological Administration, Guangzhou 510080, China \\ ${ }^{8}$ Fujian Provincial Environmental Monitoring Center, Fuzhou 350003, China \\ ${ }^{9}$ Quanzhou Municipal Bureau of Meteorology, Quanzhou 361012, China \\ ${ }^{10}$ Xiamen Municipal Bureau of Meteorology, Xiamen 362000, China
}

Correspondence to: T. L. Zhao (tlzhao@ nuist.edu.cn)

Received: 25 July 2015 - Published in Atmos. Chem. Phys. Discuss.: 10 September 2015

Revised: 16 November 2015 - Accepted: 22 November 2015 - Published: 2 December 2015

\begin{abstract}
A high $\mathrm{O}_{3}$ episode with the large increases in surface ozone by $21-42$ ppbv and the nocturnal surface $\mathrm{O}_{3}$ levels exceeding 70 ppbv was observed in the region between Xiamen and Quanzhou over the southeastern coast of China during 12-14 June 2014, before the Typhoon Hagibis landing. Variations in the surface $\mathrm{O}_{3}, \mathrm{NO}_{2}, \mathrm{CO}$ and meteorology during the Typhoon Hagibis event clearly suggest a substantial impact of the peripheral downdrafts in the large-scale typhoon circulation on such an $\mathrm{O}_{3}$ episode excluding the contributions of photochemical production and the horizontal transport. The influence of vertical $\mathrm{O}_{3}$ transport from the upper troposphere and lower stratosphere (UTLS) region on high surface $\mathrm{O}_{3}$ levels is further confirmed by a negative correlation between surface $\mathrm{O}_{3}$ and $\mathrm{CO}$ concentrations as well as dry surface air observed during the $\mathrm{O}_{3}$ episode. This study provides observational evidence of typhoon-driven intrusion of $\mathrm{O}_{3}$ from the UTLS region to surface air, revealing a significant effect of such a process of stratosphere-troposphere
\end{abstract}

exchange (STE) of $\mathrm{O}_{3}$ on tropospheric $\mathrm{O}_{3}$ and ambient air quality.

\section{Introduction}

Tropospheric $\mathrm{O}_{3}$, as an important chemical species with the effects of oxidation, toxicity and greenhouse gas on climate and environment, is generated through a series of complex photochemical reactions related to oxides of nitrogen $\left(\mathrm{NO}_{x}\right)$ and volatile organic compounds (VOC) under strong solar radiation. Both strong local photochemical production and atmospheric transport processes can lead to high surface $\mathrm{O}_{3}$ concentrations (Jacob, 1999). Weather conditions can profoundly influence tropospheric $\mathrm{O}_{3}$ levels through physical and chemical processes and their interactions that modulate $\mathrm{O}_{3}$ and its precursors (Huang et al., 2005; Xue et al., 2014). The variation of tropospheric $\mathrm{O}_{3}$ is largely influenced by the 
STE of air mass and chemical species (Holton et al., 1995; Tang et al., 2011; Hsu and Prather, 2014).

A tropical cyclone (TC), as a large-scale weather system with strong convection, is referred to as a typhoon over the western Pacific or a hurricane over the northern Atlantic. A typical TC can span a large radius of $100-2000 \mathrm{~km}$ with the vertical circulation of strong convection extending into the UTLS region at heights of $10-18 \mathrm{~km}$ (Emanuel, 1986). A three-dimensional TC circulation consists of the rotational air flow in the horizontal direction and the in-up-out-down overturning flow in the vertical direction, along which air mass near the surface can rise into thunderstorm clouds, outflowing at high levels in the UTLS and subsiding in the periphery. As an important STE mechanism, the vertical TC circulation with internal updrafts and peripheral downdrafts between the surface and the UTLS region exerts an enormous impact on air mass and energy transports in the troposphere (Baray et al., 1998; Fadnavis et al., 2011), as well as redistribution of tropospheric $\mathrm{O}_{3}$ (Baray et al., 1999).

Air intrusions from the stratosphere to the troposphere were speculated to increase $\mathrm{O}_{3}$ concentrations in the upper troposphere during a TC event (Bellevue et al., 2007). The uplift flows of $\mathrm{TC}$ also transport $\mathrm{O}_{3}$ from the surface to the middle and upper troposphere (Fadnavis et al., 2011). Under the influence of frequent typhoon activities, $\mathrm{O}_{3}$ episodes occurred over coastal areas in southeast China (Feng et al., 2007; Wu et al., 2013). The stagnant meteorological conditions with strong subsidence and stable stratification in the boundary layer resulted in pollutant accumulations with high $\mathrm{O}_{3}$ before typhoon landings over southeast China (Feng et al., 2007). The peripheral $\mathrm{O}_{3}$ was regionally transported by strong horizontal typhoon winds (Huang et al., 2006).

Convection and orographic forcing can be important for the STE and the modification of trace gases between the boundary layer and the free troposphere (Lelieveld and Crutzen, 1994; Donnell et al., 2001; Weber and Prevot, 2002; Ding et al., 2009). $\mathrm{O}_{3}$-rich air aloft could be transported downward to the surface, when the cold front passage or nocturnal residual layer "leaky" occurred (Hu et al., 2013a, b). The near-surface $\mathrm{O}_{3}$ levels abruptly increased due to the downward $\mathrm{O}_{3}$ transport from the free troposphere by tropical convections, enhancing $\mathrm{O}_{3}$ levels in the boundary layer by as much as 20 to 30 ppbv (Betts et al., 2002; Sahu and Lal, 2006; Grant et al., 2008). A recent modeling study (Hu et al., 2010) estimated that the downward transport resulted in a $39 \%$ increase in the $\mathrm{O}_{3}$ burden within the lower atmosphere $(<2 \mathrm{~km})$ during a deep moist convection event over West Africa in August 2006. These studies on downdrafts of $\mathrm{O}_{3}$ to the surface level are mostly focused on the mesoscale convections in the tropics. The extent to which these UTLS ozone enhancements reach the surface is poorly characterized.

Redistribution of tropospheric $\mathrm{O}_{3}$ by the TC circulation has been studied from the perspectives of the STE of $\mathrm{O}_{3}$, strong horizontal advection, and the stagnant meteorology

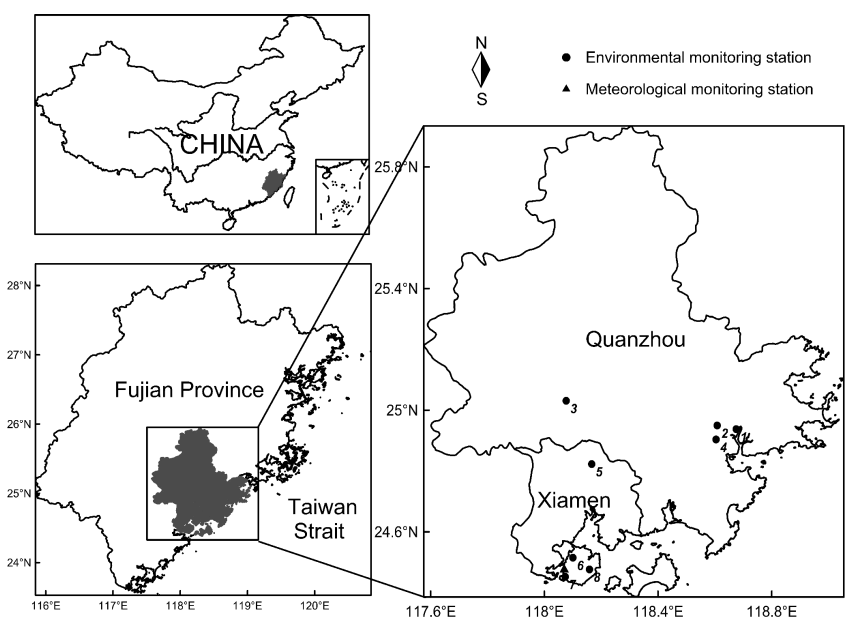

Figure 1. Locations of Fujian province in China (shaded areas, upper left panel) and the Xiamen and Quanzhou region (XQR) in Fujian province (shaded areas, lower left panel), and the distribution of nine monitoring stations (eight environmental sites with black dots numbering from 1 to 8 , and one meteorological observatory of Xiamen with a black triangle) over XQR (lower right panel).

for $\mathrm{O}_{3}$ accumulations in the boundary layer. In this study, we report a new finding on the $\mathrm{O}_{3}$-rich air downdrafts from the UTLS region to the surface driven by vertical typhoon circulation, as the deep stratospheric intrusions elevating western US of surface $\mathrm{O}_{3}$ to unhealthy levels can be classified as "exceptional events" (Lin et al., 2015). We investigate the $\mathrm{O}_{3}$ variation during a TC event of Typhoon Hagibis over northwest Pacific on the basis of observations of the surface air pollutants and meteorology in Xiamen and Quanzhou region (XQR) over the southeastern coast of China (Fig. 1) in June 2014. This study presents observational evidence of a surface $\mathrm{O}_{3}$ episode caused by downward transport of $\mathrm{O}_{3}$ in the subsiding branches of vertical TC circulation. This finding may shed some light on the function of downward $\mathrm{O}_{3}$ transport from the UTLS regions in modulating $\mathrm{O}_{3}$ in the lower troposphere with implications of the STE on air quality and climate changes.

\section{Data and observation}

The XQR area, a prefecture of Fujian province, is located on the western coast of Taiwan Strait, southeast China (Fig. 1). The air quality data (http://air.epmap.org/), including surface concentrations of $\mathrm{O}_{3}$, nitrogen dioxide $\left(\mathrm{NO}_{2}\right)$ and carbon monoxide (CO), were measured at eight environmental monitoring stations over XQR in June 2014. The surface observations of wind, air temperature, air pressure and relative humidity at the observatory of Xiamen $\left(24.48^{\circ} \mathrm{N}\right.$, $118.07^{\circ} \mathrm{E}$ ) were collected for meteorological analysis during Typhoon Hagibis in June 2014. The FNL meteorological data in a horizontal resolution of $1^{\circ} \times 1^{\circ}$ with 27 vertical lev- 


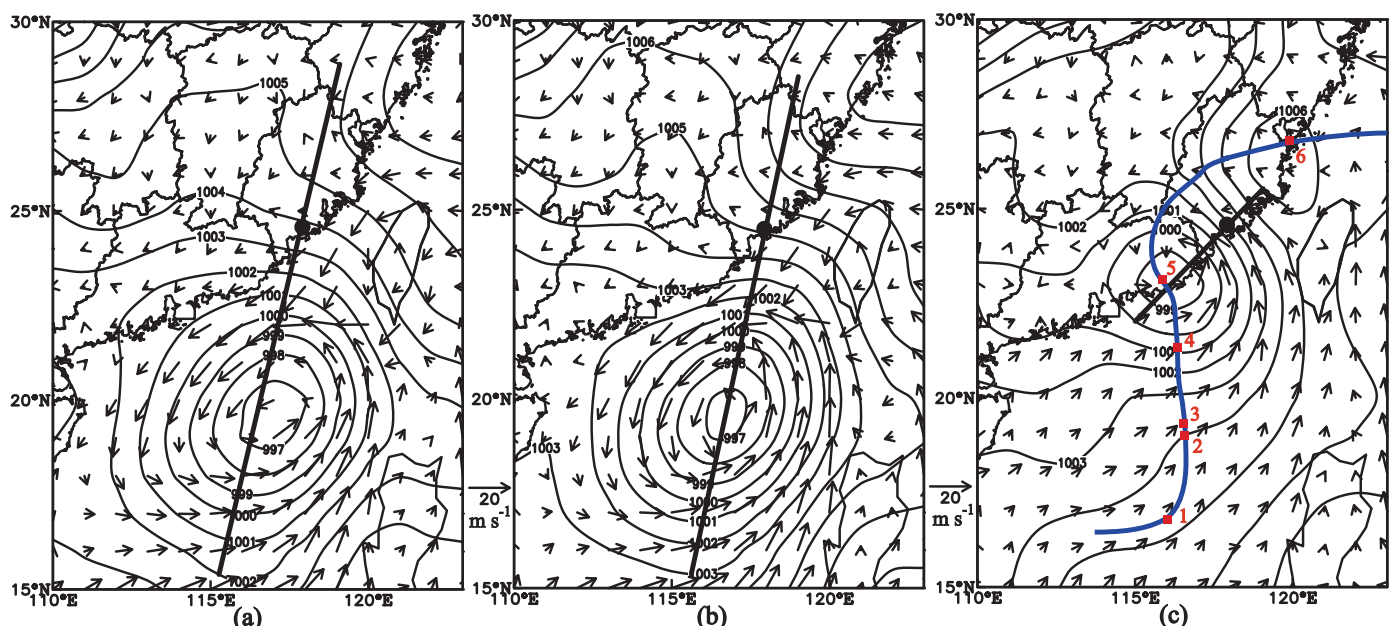

Figure 2. Sea-level air pressure (hPa, contour lines) and $1000 \mathrm{hPa}$ wind vectors of NCEP-FNL data, at (a) 14:00 13 June, (b) 20:00 13 June and (c) 20:00 15 June 2014 with black dots representing XQR location. Three straight lines link XQR and the centers of Typhoon Hagibis. The blue curve with the red dots and numbers from 1 to 6 in panel (c) indicate the typhoon track with the center locations at 02:00 12 June, 14:00 13 June, 20:00 13 June, 08:00 15 June, 20:00 15 June and 20:00 16 June (local time) respectively.

els from NCEP (National Centers for Environmental Prediction, USA) are used to describe the circulations of Typhoon Hagibis.

Typhoon Hagibis, as a summertime TC over the northwest Pacific, was intensified into a strong tropical storm over the South China Sea at Dongsha islands $\left(116.8^{\circ} \mathrm{E}, 20.6^{\circ} \mathrm{N}\right)$ and then gradually pushed northwards up the southeastern coast of China. Typhoon Hagibis made landfall in Shantou, a coastal site of Guangdong Province, south of XQR, at 16:50 15 June (local time, same for hereinafter) with the maximum sustained winds of $23 \mathrm{~m} \mathrm{~s}^{-1}$. Figure $2 \mathrm{a}-\mathrm{c}$ shows the distributions of sea-level pressure and near-surface wind fields over the region from southeast China to northwest Pacific at 14:00 13 June, 20:00 13 June and 20:00 15 June 2014 respectively, before and after the typhoon landing in the southeastern coast of China.

The hourly surface $\mathrm{O}_{3}$ concentrations over XQR during Typhoon Hagibis are shown in Fig. 3a with a noticeable anomaly in $\mathrm{O}_{3}$ concentrations before and after the typhoon landfall. XQR was situated in the typhoon periphery when Typhoon Hagibis was located in South China Sea during 12-14 June 2014 (Fig. 2a and b). A high $\mathrm{O}_{3}$ episode occurred from noon of 12 June to the afternoon of 14 June. In particular, the nocturnal surface $\mathrm{O}_{3}$ concentrations exceeded 70 ppbv from 13 to 14 June 2014 (Fig. 3c). The 8-hour averaged surface $\mathrm{O}_{3}$ concentrations of $80 \mathrm{ppbv}$ at Huli and Xidong (sites 5 and 6 in Fig. 1) in XQR reached the "hazardous" $\mathrm{O}_{3}$ level of the Chinese national standards for ambient air quality. The surface $\mathrm{O}_{3}$ obviously decreased over XQR when Typhoon Hagibis was closer to the landfall in southeast China on 15 June 2014 (Fig. 2c). By using the hourly $\mathrm{O}_{3}$ measurement data over $\mathrm{XQR}$, the normal and anomalous patterns of diurnal $\mathrm{O}_{3}$ changes could be repre- sented by the surface $\mathrm{O}_{3}$ averages over June 2014 excluding 12-14 June and over 12-14 June 2014 respectively (Fig. 3d). It is shown in Fig. 3d that the normal surface $\mathrm{O}_{3}$ levels over XQR in June 2014 shifted diurnally from $17 \mathrm{ppbv}$ at 02:00 to $52 \mathrm{ppbv}$ at $14: 00$ with a daily $\mathrm{O}_{3}$ mean of about $30 \mathrm{ppbv}$, while the anomalously high surface $\mathrm{O}_{3}$ levels during the $\mathrm{O}_{3}$ episode varied between night-time $51 \mathrm{ppbv}$ and daytime 70 ppbv with an $\mathrm{O}_{3}$ mean of about $57 \mathrm{ppbv}$. Comparing to the normal $\mathrm{O}_{3}$ levels in June 2014, the averaged enhancements of surface $\mathrm{O}_{3}$ by about $21 \mathrm{ppbv}$ in daytime and up to $42 \mathrm{ppbv}$ in night-time over $\mathrm{XQR}$ are estimated for the $\mathrm{O}_{3}$ episode before Typhoon Hagibis landing.

\section{Analysis and discussion}

The surface $\mathrm{O}_{3}$ variation is complex, which resulted from interactions of chemical production and dynamic transport on different scales (Jacob, 1999). In the following we examine this case of surface $\mathrm{O}_{3}$ peak before a typhoon landing in southeast China from chemical production, horizontal advection and vertical transport.

Tropospheric $\mathrm{O}_{3}$ is formed through a series of complex photochemical reactions of $\mathrm{NO}_{x}$ and VOC under strong solar radiation. The $\mathrm{O}_{3}$ concentrations in suburban and rural areas are usually most sensitive to $\mathrm{NO}_{x}$ variations (Chameides et al., 1992; Duncan and Chameides, 1998). Notably, the surface $\mathrm{NO}_{2}$ levels kept around $10 \mathrm{ppbv}$ during the $\mathrm{O}_{3}$ episode from 12 to 14 June, almost the same as normal $\mathrm{NO}_{2}$ levels during non-polluted days (Fig. $3 \mathrm{~b}$ and c). In particular, high $\mathrm{O}_{3}$ levels anomalously persisted during the night without photochemical reaction. Photochemical production could not be speculated to determine the high $\mathrm{O}_{3}$ episode. Furthermore, any obvious increases in surface air temperature were 

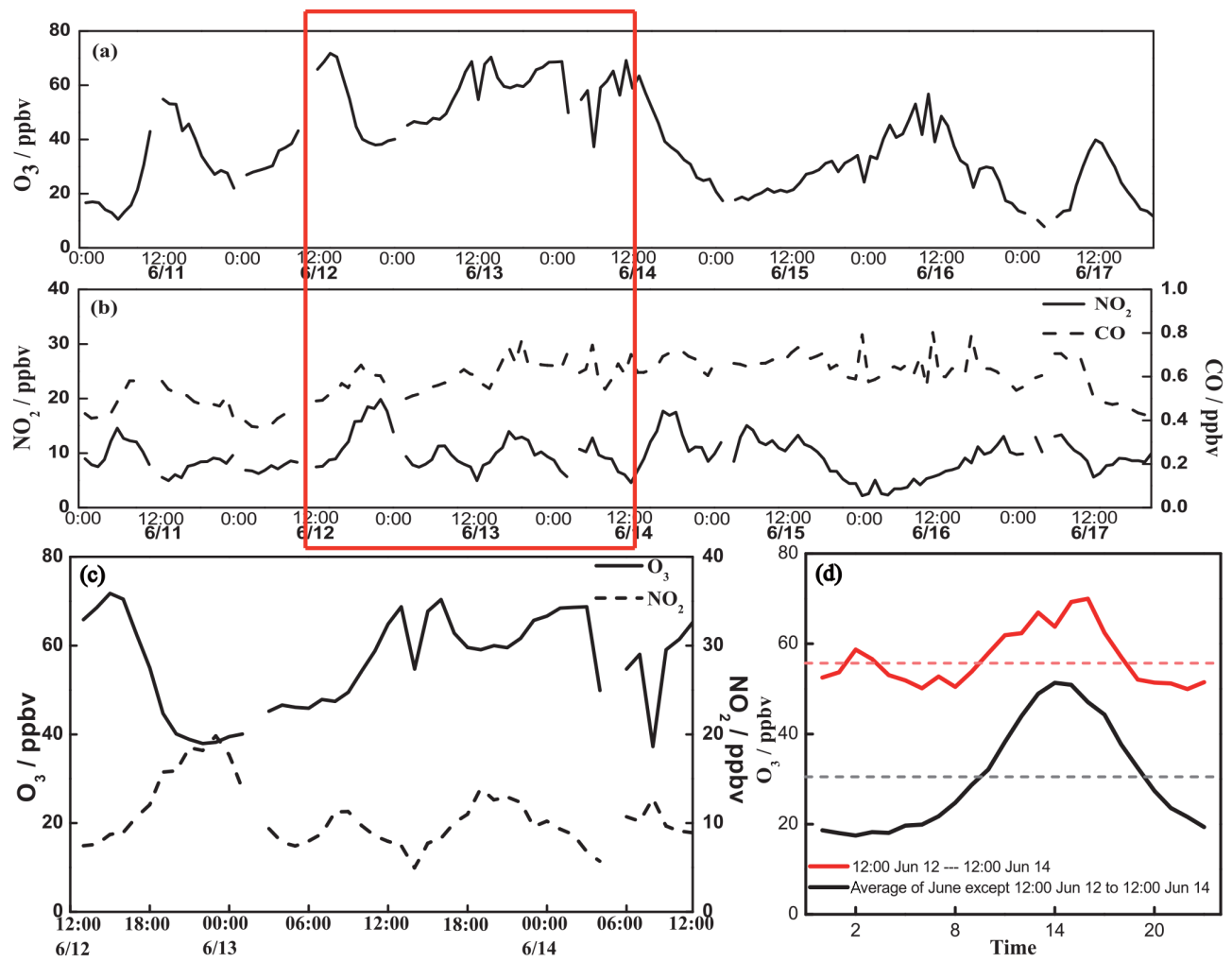

Figure 3. Hourly variations in the eight-site averaged surface concentrations of (a) $\mathrm{O}_{3}$, (b) $\mathrm{NO}_{2}$ during 11-17 June with the red rectangular column marking the period of surface $\mathrm{O}_{3}$ event and (c) $\mathrm{O}_{3}$ and $\mathrm{NO}_{2}$ for the surface $\mathrm{O}_{3}$ event over $\mathrm{XQR}$, as well as (d) diurnal changes of surface $\mathrm{O}_{3}$ from 12:00 12 June to 12:00 14 June (red curve) and in June excluding 12-14 June 2014 (black curve) with two dotted lines indicating the daily averaged $\mathrm{O}_{3}$ concentrations for two diurnal curves.

not observed for strong photochemical reactions for such high $\mathrm{O}_{3}$ production during the episode of $12-14$ June in $\mathrm{XQR}$ (Fig. 4a), since air temperature could represent the solar radiation conditions during summertime. The weather over the $\mathrm{XQR}$ region was characterized by the clear sky, strong solar radiation, weak wind, and stable atmospheric boundary layer when TC is about 600 to $1000 \mathrm{~km}$ away during the $\mathrm{O}_{3}$ episode of 12-14 June (Fig. 4). All these are favorable conditions for photochemical production of $\mathrm{O}_{3}$, which is confirmed by the diurnal variation of $\mathrm{O}_{3}$ during the episode (Fig. 3d), However, a comparison of diurnal $\mathrm{O}_{3}$ changes in June 2014 and during the $\mathrm{O}_{3}$ episode (Fig. 3d) clearly presents the anomalies in the diurnal $\mathrm{O}_{3}$ variation over 1214 June, suggesting less contribution of the local photochemical $\mathrm{O}_{3}$ production to the peak $\mathrm{O}_{3}$.

During 12-14 June, weak easterly winds over XQR (Figs. 2a, 4b) were observed to be unfavorable for horizontal transport of $\mathrm{O}_{3}$ and its precursors. The easterly wind could even carry clean air from the Pacific Ocean to XQR. Moreover, the daily change of near-surface air mass divergence over XQR clearly presented a shift of the negative to positive values for convergence and divergence conditions during normal and high $\mathrm{O}_{3}$ periods (Fig. $3 \mathrm{~b}$ ). The near-surface air mass divergence (positive values in divergence in Fig. 4b) in association with a high surface air pressure (Fig. 4c) over $\mathrm{XQR}$ suppressed the advection import $\mathrm{O}_{3}$ and its precursors towards XQR during the $\mathrm{O}_{3}$ episode of 12-14 June 2014. The meteorological conditions of easterly clean air from ocean and near-surface air divergence over XQR were unfavorable to horizontal transport of air pollutants to $\mathrm{XQR}$ during the $\mathrm{O}_{3}$ episode. Therefore, the surface $\mathrm{O}_{3}$ peak of 12-14 June before the typhoon landing was unlikely caused by horizontal advection or transport of $\mathrm{O}_{3}$ and its precursors.

Figure 5 presents the cross sections of vertical velocity along the lines from the typhoon center to XQR (as shown in Fig. 2 with the black solid lines) at 14:00 and 20:00 13 June, as well as 20:00 15 June 2014 respectively. Along with the strong rising motions from the surface up to the UTLS around $100 \mathrm{hPa}$ near the typhoon center (Fig. 5a and b), the subsiding branches of vertical typhoon circulation were located over XQR in the northeastern periphery of Typhoon Hagibis at 14:00 and 20:00 13 June 2014 (Figs. 2a, $\mathrm{b}$ and $5 \mathrm{a}, \mathrm{b})$. A typical structure of TC circulation with the in-up-out-down overturning flows in the vertical direction built up the internal updrafts and peripheral downdrafts for air mass exchange between the surface level and the UTLS region (Fig. 5a and b). The well-organized deep and strong downdrafts occurred over XQR during this episode before 

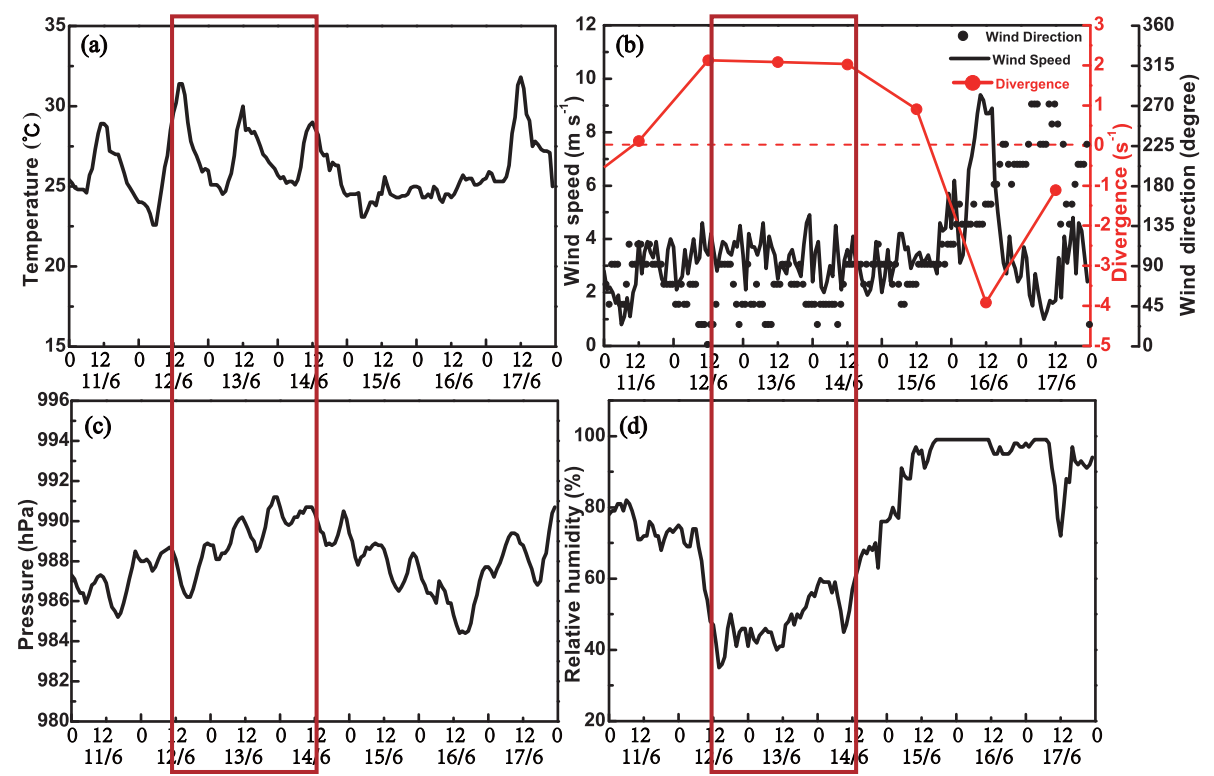

Figure 4. Time series of (a) surface air temperature (b) wind speed, direction and divergence, (c) air pressure and (d) relative humidity observed in the observatory of Xiamen from 11 to 17 June 2014 with the red rectangular columns marking the period of surface $\mathrm{O}_{3}$ event. The red curve in panel (b) is a daily variation in divergences at $1000 \mathrm{hPa}$ over XQR, calculated with NCEP-FNL data.

the typhoon landfall with the subsiding velocity exceeding $20 \mathrm{~Pa} \mathrm{~s}^{-1}$ at 14:00 and 20:00 in 13 June. As Typhoon Hagibis approached and landed at the coast in southeast China (Fig. 2), the downdrafts were changed to the updrafts over $\mathrm{XQR}$ on 15 June (Fig. 5c), and the surface $\mathrm{O}_{3}$ concentrations dropped to the normal levels over XQR (Fig. 3a).

A climatological pattern of vertical $\mathrm{O}_{3}$ distribution presents the uniquely elevated $\mathrm{O}_{3}$ concentrations in the UTLS region (Liu et al., 2013). The large-scale convections of Typhoon Hagibis were fully developed and well organized with strong uplifts reaching to the UTLS around $100 \mathrm{hPa}$ and consecutively downward flows to the surface level over XQR (Fig. 5a, b), which could efficiently deliver $\mathrm{O}_{3}$-rich air from the UTLS region to the surface leading to the surface $\mathrm{O}_{3}$ enhancement by about $27 \mathrm{ppbv}$ in daytime and up to $40 \mathrm{ppbv}$ in night-time observed over XQR during 12-14 June (Fig. 3c, d). Furthermore, low relative humidity and high air pressure on the XQR surface during 12-14 June (Fig. 4c and d) add evidences for the strong downward transport of $\mathrm{O}_{3}$ in the subsiding branches of TC with dry air mass of the UTLS region affecting the surface air, given that surface relative humidity dropped sharply (Fig. 4d) and air temperature decreased slightly (Fig. 4a) over XQR during 12-14 June. Therefore, it is the downdrafts of $\mathrm{O}_{3}$-rich air from the UTLS that played a decisive role in the formation of $\mathrm{O}_{3}$ episode before a typhoon landing in southeast China.

The correlation between $\mathrm{O}_{3}$ and $\mathrm{CO}$ has been widely used to identify sources of tropospheric $\mathrm{O}_{3}$. When $\mathrm{O}_{3}$ and $\mathrm{CO}$ are positively correlated, $\mathrm{O}_{3}$ is usually originated from the anthropogenic sources with photochemical reactions (Parrish et al., 1998; Voulgarakis et al., 2011). A negative correlation of $\mathrm{O}_{3}$ and $\mathrm{CO}$ generally indicates the vertical $\mathrm{O}_{3}$ transport from the upper atmosphere, where air is poor in $\mathrm{CO}$ but rich in $\mathrm{O}_{3}$ (Moody et al., 1995; Parrish et al., 1998). The correlations between hourly $\mathrm{CO}$ and $\mathrm{O}_{3}$ concentrations measured at eight sites in $\mathrm{XQR}$ are shown over two periods from 12:00 11 June to 12:00 12 June and from 12:00 13 June to 12:00 14 June, respectively (Fig. 6). In contrast to a significantly positive correlation of the $\mathrm{CO}$ and $\mathrm{O}_{3}$ during the first period, reflecting a dominant role of anthropogenic sources in the $\mathrm{O}_{3}$ changes (Fig. 6a), the $\mathrm{CO}$ and $\mathrm{O}_{3}$ concentrations were negatively correlated (significantly at $P<0.005$ ) during the second period (Fig. 6b), further confirming that the $\mathrm{O}_{3}$ episode with nocturnal high $\mathrm{O}_{3}$ over $\mathrm{XQR}$ was largely contributed by downward transport of $\mathrm{O}_{3}$-rich air in the peripheral subsidence of Typhoon Hagibis. For interpreting the enhanced $\mathrm{CO}$ concentrations during the $\mathrm{O}_{3}$ episode (Fig. $6 \mathrm{a}$ and $\mathrm{b}$ ), we may consider the atmospheric removal of $\mathrm{CO}$ by hydroxyl radical $(\mathrm{OH})$. It is well-known that $\mathrm{O}_{3}$ photolysis produces $\mathrm{O}^{1} \mathrm{~d}$, which react with $\mathrm{H}_{2} \mathrm{O}$ to produce $2 \mathrm{OH}$, and the reaction of $\mathrm{CO}$ with $\mathrm{OH}$ forms the stable end product of carbon dioxide $\left(\mathrm{CO}_{2}\right)$ (Seinfeld and Spyros, 2006). In the situation of normal photochemical production (Fig. 6a), high $\mathrm{O}_{3}$ could lead to more $\mathrm{OH}$ production and consequently lower $\mathrm{CO}$. In the situation of peripheral $\mathrm{O}_{3}$-rich air subsidence of the typhoon, the downward dry air (Fig. 4d) with lower abundance of $\mathrm{OH}$ radicals could decrease the removal of $\mathrm{CO}$. This would result in $\mathrm{CO}$ accumulation and consequently high $\mathrm{CO}$ concentrations, and high $\mathrm{CO}$ accumulation within boundary layer could overwhelm the dilution of CO-poor air from the UTLS during the high $\mathrm{O}_{3}$ episode. 

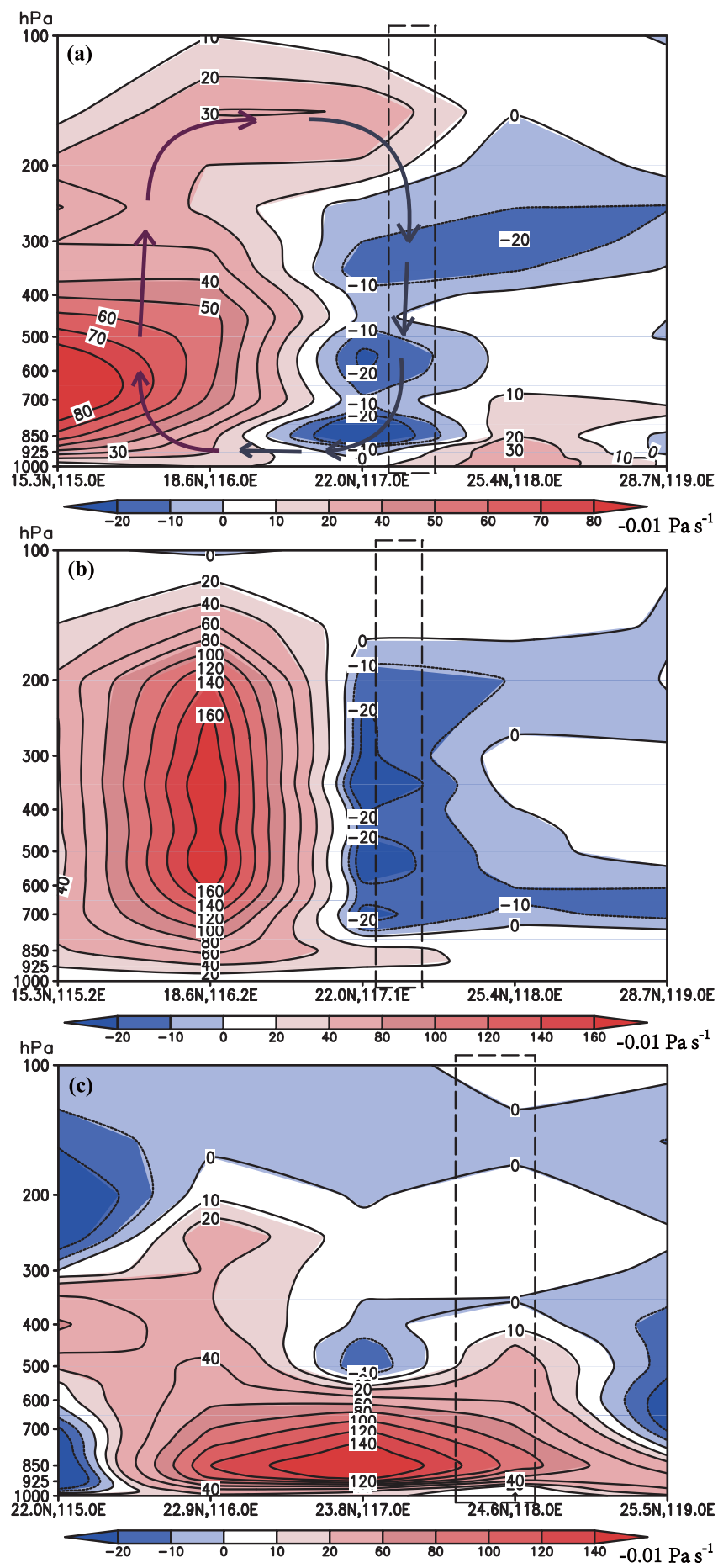

Figure 5. Vertical cross sections of vertical velocity $\left(-0.01 \mathrm{~Pa} \mathrm{~s}^{-1}\right)$ along the three straight lines linking XQR and the centers of Typhoon Hagibis in Fig. 2 at (a) 14:00 13 June, (b) 20:00 13 June and (c) 20:00 15 June 2014. Two dashed boxes denote the location of $\mathrm{XQR}$. The lines with arrows indicate the in-up-out-down overturning air flows in the vertical direction of typhoon.
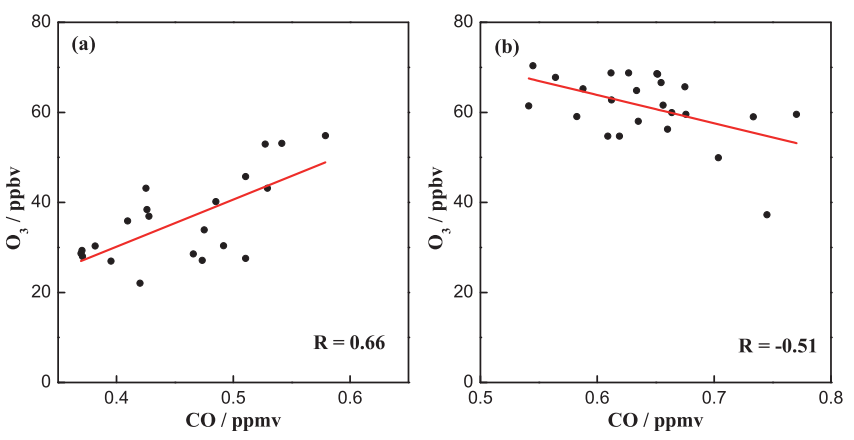

Figure 6. Correlations between measured surface $\mathrm{CO}$ and $\mathrm{O}_{3}$ over two periods respectively (a) from 12:00 11 June to 12:00 12 June and (b) from 12:00 13 June to 12:00 14 June 2014, passing the significant level of 0.005 . Red lines are the linear fittings.

\section{Summary}

This observation study presents an $\mathrm{O}_{3}$ episode due to downward transport from the UTLS to surface air in the peripheral TC subsidence over the southeastern coast of China. A high $\mathrm{O}_{3}$ event during 12-14 June 2014 was observed with the nocturnal surface $\mathrm{O}_{3}$ levels exceeding $70 \mathrm{ppbv}$ and large enhancements of surface $\mathrm{O}_{3}$ concentrations by about $21 \mathrm{ppbv}$ in daytime and up to $42 \mathrm{ppbv}$ in night-time. The ground observations of $\mathrm{O}_{3}, \mathrm{NO}_{2}$ and $\mathrm{CO}$ accompanying meteorology from both observations and reanalysis over XQR during the event of Typhoon Hagibis are examined to assess the contributions of chemical production, horizontal advection and vertical transport to the $\mathrm{O}_{3}$ episode.

As the contributions of horizontal advection and chemical production to surface $\mathrm{O}_{3}$ enhancement in the $\mathrm{O}_{3}$ episode are excluded, the peripheral subsiding branches in the TC circulation bringing $\mathrm{O}_{3}$-rich air from the UTLS to surface air are identified to be responsible for peaking the surface $\mathrm{O}_{3}$ levels over the southeastern coast of China during 12-14 June 2014 before the landfall of Typhoon Hagibis. This rational analysis is further supported by a significantly negative correlation between the surface $\mathrm{O}_{3}$ and $\mathrm{CO}$ as well as the dry surface air observed during the $\mathrm{O}_{3}$ episode.

This case study of Typhoon Hagibis provides observational evidence of TC-driven vertical transport of $\mathrm{O}_{3}$ from the UTLS region to the surface, revealing a significant effect of such a process of STE of $\mathrm{O}_{3}$ on deterioration of air quality. Evidence suggests deep stratospheric intrusions can elevate surface $\mathrm{O}_{3}$ to unhealthy levels before a typhoon landing in southeast China. Stratospheric $\mathrm{O}_{3}$ is a natural source dominating tropospheric $\mathrm{O}_{3}$ pollution in this scenario. Considering the frequency and distribution of $\mathrm{TC}$ in the world and their impact on STE, this finding has implications on tropospheric $\mathrm{O}_{3}$ as well as environment and climate changes. Tropical cyclones, as an important STE mechanism, could exert an enormous impact on air mass and energy transports 
in the troposphere, as well as redistribution of tropospheric ozone.

A pattern of well-organized deep TC convection for the exchange of chemical species between the UTLS and surface air is depicted in this case study of TC in southeast China. Based on the understanding of the dynamical structure of TC and the chemical distribution in the atmosphere, the strong subsiding branches of vertical TC circulation could unusually transport the upper $\mathrm{O}_{3}$-rich air to the surface in any TC events, which is to be further studied with more comprehensive observations to characterize the extent to which these UTLS ozone enhancements reach the surface. The implications of this finding on environment and climate changes need to be explored by using coupled meteorology-chemistry models.

Acknowledgements. This work was jointly funded by National Science and Technology Project of China (2014BAC22B04), the Key Basic Research Program of China (2014CB441203), the Science and Technology Support Program of Jiangsu Province, China (BE2012771), and National Natural Science Foundation of China (40906023). This paper is the ESMC publication number 077. The air quality data were obtained freely from the Chinese Ministry of Environmental Protection (http://air.epmap.org/). The NCEP-FNL meteorological data were freely downloaded from the NOAA-CIRES Climate Diagnostics Center, Boulder, Colorado, USA (http://rda.ucar.edu).

Edited by: L. Zhang

\section{References}

Baray, J. L., Ancellet, G., Taupin, F. G., Bessafi, M., Baldy, S., and Keckhut, P.: Subtropical tropopause break as a possible stratospheric source of ozone in the tropical troposphere, J. Atmos. Sol.-Terr. Phy., 60, 27-36, doi:10.1016/S1364-6826(97)001168, 1998.

Baray, J. L., Ancellet, G., Randriambel, T., and Baldy, S.: Tropical cyclone Marlene and stratosphere-troposphere exchange, J. Geophys. Res., 104, 13953-13970, doi:10.1029/1999JD900028, 1999.

Bellevue, J., Baray, J. L., Baldy, S., Ancellet, G., Diab, R. D., and Ravetta, F.: Simulations of stratospheric to tropospheric transport during the tropical cyclone Marlene event, Atmos. Environ., 41, 6510-6526, doi:10.1016/j.atmosenv.2007.04.040, 2007.

Betts, A. K., Gatti, L. V., Cordova, A. M., Silva Dias, M. A. F., and Fuentes, J. D.: Transport of ozone to the surface by convective downdrafts at night, J. Geophys. Res., 107, 8046, doi:10.1029/2000JD000158, 2002.

Chameides, W. L., Fehsenfeld, F., Rodgers, M. O., Cardelino, C., Martinez, J., Parrish, D., Lonneman, W., Lawson, D. R., Rasmussen, R. A., Zimmerman, P., Greenberg, J., Middleton, P., and Wang, T.: Ozone precursors relationships in the ambient atmosphere, J. Geophys. Res., 97, 6037-6055, doi:10.1029/91JD03014, 1992.
Ding, A., Wang, T., Xue, L., Stohl, A., Lei, H., Jin, D., Ren, Y., Wang, X., Wei, X., Qi, Y., Liu, J., and Zhang, X.: Transport of north China air pollution by midlatitude cyclones: Case study of aircraft measurements in summer 2007, J. Geophys. Res., 114, D08304, doi:10.1029/2008JD011023, 2009.

Donnell, E. A., Fish, D. J., Dicks, E. M., and Thorpe, A. J.: Mechanisms for pollutant transport between the boundary layer and the free troposphere, J. Geophys. Res., 106, 7847-7856, doi:10.1029/2000JD900730, 2001.

Duncan, B. N. and Chameides, W. L.: Effects of urban emission control strategies on the export of ozone and ozone precursors from the urban atmosphere to the troposphere, J. Geophys. Res., 103, 28159-28179, doi:10.1029/98JD02145, 1998.

Emanuel, K. A.: An air-sea interaction theory for tropical cyclones. Part I: steady-state maintenance, J. Atmos. Sci., 43, 585-605, doi:10.1175/1520-0469(1986)043<0585:AASITF>2.0.CO;2, 1986.

Fadnavis, S., Berg, G., Buchunde, P., Ghude, S. D., and Krishnamurti, T. N.: Vertical transport of ozone and $\mathrm{CO}$ during super cyclones in the Bay of Bengal as detected by Tropospheric Emission Spectrometer, Environ. Sci. Pollut. R., 18, 301-315, doi:10.1007/s11356-010-0374-3, 2011.

Feng, Y., Wang, A., Wu, D., and Xu, X.: The influence of tropical cyclone Melor on $\mathrm{PM}_{10}$ concentrations during an aerosol episode over the Pearl River Delta region of China: Numerical modeling versus observational analysis, Atmos. Environ., 41, 4349-4365, doi:10.1016/j.atmosenv.2007.01.055, 2007.

Grant, D. D., Fuentes, J. D., DeLonge, M. S., Chan, S., Joseph, E., Kucera, P., Ndiaye, S. A., and Gaye, A. T.: Ozone transport by mesoscale convective storms in western Senegal, Atmos. Environ., 42, 7104-7114, doi:10.1016/j.atmosenv.2008.05.044, 2008.

Holton, J. R., Haynes, P. H., McIntyre, M. E., Douglass, A. R., Rood, R. B., and Pfister, L.: Stratosphere-troposphere exchange, Rev. Geophys., 33, 403-439, 1995.

Hsu, J. and Prather, M. J.: Is the residual vertical velocity a good proxy for stratosphere-troposphere exchange of ozone?, Geophys. Res. Lett., 41, 9024-9032, doi:10.1002/2014GL061994, 2014.

Hu, X. M., Fuentes, J. D., and Zhang, F.: Downward transport and modification of tropospheric ozone through moist convection, J. Atmos. Chem., 65, 13-35, doi:10.1007/s10874-010-9179-5, 2010.

Hu, X. M., Klein, P. M., Xue, M., Shapiro, A., and Nallapareddy, A.: Enhanced vertical mixing associated with a nocturnal cold front passage and its impact on near-surface temperature and ozone concentration, J. Geophys. Res., 118, 2714-2728, doi:10.1002/jgrd.50309, 2013a.

Hu, X. M., Klein, P. M., Xue, M., Zhang, F., Doughty, D. C., Forkel, R., Joseph, E., and Juentes, J. D.: Impact of the vertical mixing induced by low-level jets on boundary layer ozone concentration, Atmos. Environ., 70, 123-130, doi:10.1016/j.atmosenv.2012.12.046, 2013b.

Huang, J. P., Fung, C. H., Lau, K. H., and Qin, Y.: Numerical simulation and process analysis of typhoon-related ozone episodes in Hong Kong, J. Geophys. Res., 110, D05301, doi:10.1029/2004JD004914, 2005.

Huang, J. P., Fung, C. H., and Lau, K. H.: Integrated processes analysis and systematic meteorological classification of 
ozone episodes in Hong Kong, J. Geophys. Res., 111, D20309, doi:10.1029/2005JD007012, 2006.

Jacob, D. J.: Introduction of Atmospheric Chemistry, Princeton Univ. Press, Princeton, N. J., USA, 234-243, 1999.

Lelieveld, J. and Crutzen, P. J.: Role of deep cloud convection in the ozone budget of the troposphere, Science, 264, 793-797, 1994.

Lin, M., Fiore, A. M., Horowitz, L. W., Langford, A. O., Oltmans, S. J., Tarasick, D., and Rieder, H. E.: Climate variability modulates western US ozone air quality in spring via deep stratospheric intrusions, Nature, 6, 7105, doi:10.1038/ncomms8105, 2015.

Liu, J., Tarasick, D. W., Fioletov, V. E., McLinden, C., Zhao, T., Gong, S., Sioris, C., Jin, J. J., Liu, G., and Moeini, O.: A global ozone climatology from ozone soundings via trajectory mapping: a stratospheric perspective, Atmos. Chem. Phys., 13, 1144111464, doi:10.5194/acp-13-11441-2013, 2013.

Moody, J. L., Oltmans, J., and Merrill, T.: Transport climatology of tropospheric ozone: Bermuda, 1988-1991, J. Geophys. Res., 100, 7179-7194, doi:10.1029/94JD02830, 1995.

Parrish, D. D., Trainer, M., Holloway, J. S., Yee, J. E., Warshawsky, M. S., Fehsenfeld, F. C., Forbes, G. L., and Moody, J. L.: Relationships between ozone and carbon monoxide at surface sites in the North Atlantic region, J. Geophys. Res., 103, 13357-13376, 1998.

Sahu, L. K. and Lal, S.: Changes in surface ozone levels due to convective downdrafts over the Bay of Bengal, Geophys. Res. Lett., 33, L10807, doi:10.1029/2006GL025994, 2006.
Seinfeld, J. H. and Spyros, N. P.: Atmospheric Chemistry and Physics: From Air Pollution to Climate Change, 2nd edition, J. Wiley, New York, USA, 2006.

Tang, Q., Prather, M. J., and Hsu, J.: Stratosphere-troposphere exchange ozone flux related to deep convection, Geophys. Res. Lett., 38, L03806, doi:10.1029/2010GL046039, 2011.

Voulgarakis, A., Telford, P. J., Aghedo, A. M., Braesicke, P., Faluvegi, G., Abraham, N. L., Bowman, K. W., Pyle, J. A., and Shindell, D. T.: Global multi-year $\mathrm{O}_{3}-\mathrm{CO}$ correlation patterns from models and TES satellite observations, Atmos. Chem. Phys., 11, 5819-5838, doi:10.5194/acp-11-5819-2011, 2011.

Weber, R. O. and Prevot, A. S. H.: Climatology of ozone transport from the free troposphere into the boundary layer south of the Alps during North Foehn, J. Geophys. Res., 107, 4030, doi:10.1029/2001JD000987, 2002.

Wu, M., Wu, D., Fan, Q., Wang, B. M., Li, H. W., and Fan, S. J.: Observational studies of the meteorological characteristics associated with poor air quality over the Pearl River Delta in China, Atmos. Chem. Phys., 13, 10755-10766, doi:10.5194/acp13-10755-2013, 2013.

Xue, L. K., Wang, T., Gao, J., Ding, A. J., Zhou, X. H., Blake, D. R., Wang, X. F., Saunders, S. M., Fan, S. J., Zuo, H. C., Zhang, Q. Z., and Wang, W. X.: Ground-level ozone in four Chinese cities: precursors, regional transport and heterogeneous processes, Atmos. Chem. Phys., 14, 13175-13188, doi:10.5194/acp14-13175-2014, 2014. 